\title{
Monitoring the diversity, abundance, activity period and habitat use of wildlife species around the wildlife corridor that connects the natural world heritage site in Thailand
}

\author{
MANANYA PLA-ARD, NORASET KHIOESREE, BUNYATIPORN KEAWDEE, WIPAVEE HUNGHENG, \\ PATTANAPHON CHATTRAKULDEE, PHANITSUPHA PENGTHONG, JIDAPA THONGBANTHUM, \\ PAANWARIS PAANSRI, KHWANRUTAI CHARASPET, TANAPONE PANGANTA, \\ YUWARAK CHANACHAI, PRATEEP DUENGKAE, DOKRAK MAROD, SUWIMOL UTHAIRASMEE, \\ THARNRAT KAEWKRACHANG, NARIS BHUMPAKPHAN, YONGYUT TRISURAT, \\ WARONG SUKSAVATE, SARAWOOD SUNGKAEW, NANTACHAI PONGPATTANANURAK, \\ PHRUET RACHARAK, DECHA WIWATWITTAYA, WATTANACHAI TASEN, RONGLARP SUKMASUANG ${ }^{*}$ \\ Department of Forest Biology, Faculty of Forestry, Kasetsart University. 50 Phahonyothin Road, Chatuchak District, Bangkok 10900, Thailand. \\ Tel.: +66-2-579-0176, Fax.: +66-2-942-8107, `email: mronglarp@ gmail.com
}

Manuscript received: 10 October 2021. Revision accepted: 24 October 2021.

\begin{abstract}
Pla-Ard M, Khioesree N, Keawdee B, Hungheng W, Chattrakuldee P, Pengthong P, Thongbanthum J, Paansri P, Charaspet $K$, Panganta T, Chanachai Y, Duengkae P, Marod D, Uthairasmee S, Kaewkrachang T, Bhumpakphan N, Trisurat Y, Suksavate W, Sungkaew S, Pongpattananurak N, Racharak P, Wiwatwittaya D, Tasen W, Sukmasuang R. 2021. Monitoring the diversity, abundance, activity period and habitat use of wildlife species around the wildlife corridor that connects the natural world heritage site in Thailand. Biodiversitas 22: 4983-4996. The development of roads and highways has a significant impact on biodiversity Moreover, the highway is developed by dissecting protected areas. Highway 304 in Thailand cuts through Khao Yai National Park (KYNP) and Thap Lan National Park (TLNP), areas assigned as World Natural Heritage Site. This study aimed to monitor the diversity and abundance of wildlife around the wildlife corridor area on the Highway 304 and study the animal period of activity and the factors that affect the distribution of wildlife in the area. The study was conducted during September 2017 and May 2021 using camera traps to monitor the area constantly. A total of 51 wildlife species from 30 families and 14 orders were recorded. The species with the highest abundances were Sambar Deer, Wild Boar, Northern Pig-tailed Macaque, Gaur, Northern Red Muntjac, Siamese Fireback, Malayan Porcupine and Red Junglefowl. The wildlife species recorded included 2 Critically Endangered species, 3 Endangered, 10 Vulnerable and 1 Near Threatened. In this study, we also recorded images of a Fishing Cat, the first photographically recorded in this World Heritage Site. The evenness index indicates that the wildlife community in the area was stable. No significant differences in the diversity and abundance of wildlife before or after the corridor construction were seen. The wildlife in the area was active throughout the day. We also found that the highway was the main factor affecting the presence of wildlife. The study results show the importance of wildlife corridors between the two national parks for maintaining the wildlife community and continuity. Suggestions from the study include the restriction of traffic, noise, vehicle speed and other activities that may attract wildlife closer to the community and cause other impacts.
\end{abstract}

Keywords: Camera trapping, Dong Phayayen-Khao Yai Forest Complex, Wildlife corridor

\section{INTRODUCTION}

The construction of transportation networks, including roads and highways, has a significant impact on biodiversity (Halfwerk et al. 2011; Laurance and Balmford 2013). The number and extent of roads will expand dramatically this century. Globally, at least 25 million kilometers of new roads are anticipated by 2050 (Laurance et al. 2014). Nine-tenths of all road construction is expected to occur in developing nations, including many regions that sustain exceptional biodiversity and vital ecosystem services. Furthermore, approximately half of all roads occurred in forests, mainly historically exploited forests (Sloan et al. 2018). As a result, roads were penetrating wilderness or frontier areas area major proximate driver of habitat loss and fragmentation, wildfires, overhunting and other environmental degradation, often with irreversible impacts on ecosystems (Laurance et al. 2014). Unfortunately, much road proliferation is chaotic or poorly planned, and the threat of expansion is so significant that it often overwhelms the capacity of environmental planners and managers (Laurance et al. 2014). In many cases, the development of roads and highways drives deforestation and forest fragmentation, reducing biodiversity and habitat stability and influencing the behavior of wild animals (Fahrig and Rytwinski 2009).

When operational, highways can directly cause the death of wildlife through collision. They also cause injuries to wild animals, reducing the health quality, welfare and long-term survival of such wildlife (Polak et al. 2014). While not causing direct damages, traffic noises from the highways affect various types of wildlife. For example, it hurts the reproduction ability of wild birds (Berthinussen 
and Altringham 2012; Northrup et al. 2012) and amphibians that use vocalization during their reproductive activities (Caorsi et al. 2017). Traffic noise also has a detrimental effect on the vigilance of wild mammals (Shannon et al. 2016), whether carnivores or prey species, due to communication problems of the wildlife (Duquette et al. 2021).

Highway 304 in Thailand was developed to be the main route connecting the country's eastern and northeastern regions. This highway cuts through Khao Yai National Park (KYNP) and Thap Lan National Park (TLNP), which are parts of the Dong Phaya Yen-Khao Yai Forest Complex World Natural Heritage Site declared by UNESCO in 2005 (UNESCO 2021). There are two non-continuous sections where the highway cuts through the two national parks. The first section is three kilometers long and the second section is approximately 16 kilometers long, adding to approximately 19 kilometers. Wildlife corridors were constructed to connect the two national parks in both sections, following the conditions set by IUCN (2005) to enable wildlife to move freely between the two areas, huge animals of both carnivorous and herbivorous species. The corridors in the first three $\mathrm{km}$ long section are divided into two parts, including a $1,200 \mathrm{~m}$ underpass and a $430 \mathrm{~m}$ overpass. The second $16 \mathrm{~km}$ long corridors include one 500 $\mathrm{m}$ underpass in the hillside (slope) area and several overpasses and elevated bridges are under construction.

Sawongfu et al. (2011) studied wildlife species along Highway 304 and found 23 mammalian species from 7 orders and 15 families, e.g., Asian Elephant, Gaur, Sambar Deer, Malayan Sun Bear, Asiatic Black Bear, Red Muntjac, Wild Boar, Serow, Pig-tailed Macaque, Golden Jackal, Dhole, etc. In contrast, Sukmasuang et al. (2020a) reported wildlife species along the wildlife corridor in the first $3 \mathrm{~km}$ section recorded by camera traps deployed from September 2017 to November 2018, with a total of 3,172 trap nights. The number of species found in the study collated from a total of 6,707 images included 13 herbivorous species, 10 carnivorous species, 10 wild bird species and 4 reptile species, adding up to a total of 37 species from 14 orders and 26 families. Within these species, four are categorized as Endangered by the IUCN (2019), including Dhole, Large Spotted Civet, Sunda Pangolin and Asian Giant Tortoise. In addition, five species are categorized as Vulnerable and 21 are Least Concern species.

Although a study on the wildlife diversity along the forest corridors of Highway 304 has been conducted by Sukmasuang et al. (2020a), this was only performed along the corridors in the first $3 \mathrm{~km}$ section, while a similar study in the corridors of $16 \mathrm{~km}$ section is lacking. Further studies are needed to reveal the species abundance, the suitability of the habitat area and environmental factors along both sections of the wildlife corridor, and the community areas along the highway, which are approximately $56 \mathrm{~km}$. When analyzing the overall spatial data, it will be helpful to investigate various management aspects along the wildlife corridors connecting the two national parks. Research is required to answer the hypothesis of whether there is a difference in species diversity and abundance across three time periods, i.e., before the opening, at the time of the opening and after the opening of the wildlife corridor. Also, it would be essential to study factors that affect the presence of wildlife along the highway where the wildlife corridor is constructed.

The objectives of this study are: (i) to study the annual wildlife diversity along the whole Highway 304 that passes through KYNP and TLNP from 2017 - 2021; (ii) to compare the diversity of wildlife between before and after the construction of the wildlife corridors; (iii) to study the animal presence in time and the factors that affect the distribution of wildlife in the area. The expected results of this study allow us to understand the use of wildlife around wildlife corridors based on the diversity and abundance of various wildlife species that can use to determine the pattern of wildlife corridors to suit the species of wildlife in the next phase. Changes in wildlife use before and after the creation of wildlife corridors to confirm the importance of the area and corridor project. Physical and biological factors in the area that affect wildlife presence are used to select management methods that shape human activities to reduce the impact for maintaining the abundance and diversity in the area that can continue to operate in this crucial area.

\section{MATERIALS AND METHODS}

\section{Study area}

The study was conducted along the sections of Highway 304 that pass through KYNP and TLNP. The forests that the highway passes through on the KYNP side are dry evergreen and moist evergreen forests, whereas on the TLNP side are mountainous terrains with mixed deciduous and bamboo forests, and in some parts of the area, there are deciduous dipterocarp forests interspersed with grasslands, which were formed by settlements in the past. Various plants, especially Indochinese fan palm (Corypha lecomtei), are distributed throughout the area.

The general condition of the study area is characterized by hills and mountains with a stream running parallel to the route studied. In general, the forest condition in TLNP is mainly mixed deciduous forest interspersed with dry evergreen forests along the stream, and some parts are secondary forests. While the forest in KYNP is a primarily dry evergreen forest with thick forest canopy coverage, thus, little light can penetrate through to the ground causing high humidity all year round. The characteristics of the first corridor construction section include a 6-meter-high overpass for wildlife to pass under with a total length of 1,200 meters and a 430 meters long car tunnel (Figure 1). IUCN (2005) reported that the plant community in the area between KYNP and TLNP is an alternation of dry evergreen forest, mixed deciduous forest and deciduous dipterocarp forest. Grassland areas are also found in some areas of the two national parks inhabited by large herbivorous species such as Gaur, Banteng, and Sambar Deer. In addition, the park is the only area occupied by tigers in the Northeast of Thailand.

Data were collected along the side of Highway 304 where the wildlife corridors were constructed. The first 
section is approximately 3 kilometers, and the second section is approximately 15 kilometers. Camera traps were deployed on both sides of the route along the entire length with the distance from the first position to the last position being approximately 28 kilometers.

\section{Climate}

The mean annual temperature is $28.3^{\circ} \mathrm{C}$, with the mean highest and the lowest temperature being $33.9^{\circ} \mathrm{C}$ and $23.8^{\circ} \mathrm{C}$, respectively. The highest temperature recorded was $42.9^{\circ} \mathrm{C}$ on 23 April 1990 in Krabinburi District, Prachinburi and the lowest temperature measured was $8.5^{\circ} \mathrm{C}$ in Krabinburi District, Prachinburi on 30 December 1975. From the 30-year data record, it is found that the average lowest temperature is in January measuring $18.5^{\circ} \mathrm{C}$ and the highest is in April, measuring $36.5^{\circ} \mathrm{C}$. The annual precipitation is between $1,600-1,900 \mathrm{~mm}$, especially in August and September, with the highest rainfall. The average rainfall per year is $130-140$ days. In addition, there may be rainstorms moving through in some years, which increase the amount and distribution of rain. The most significant amount of rainfall measured in 24 hours was 194.9 mm (Meteorological Department 2020).

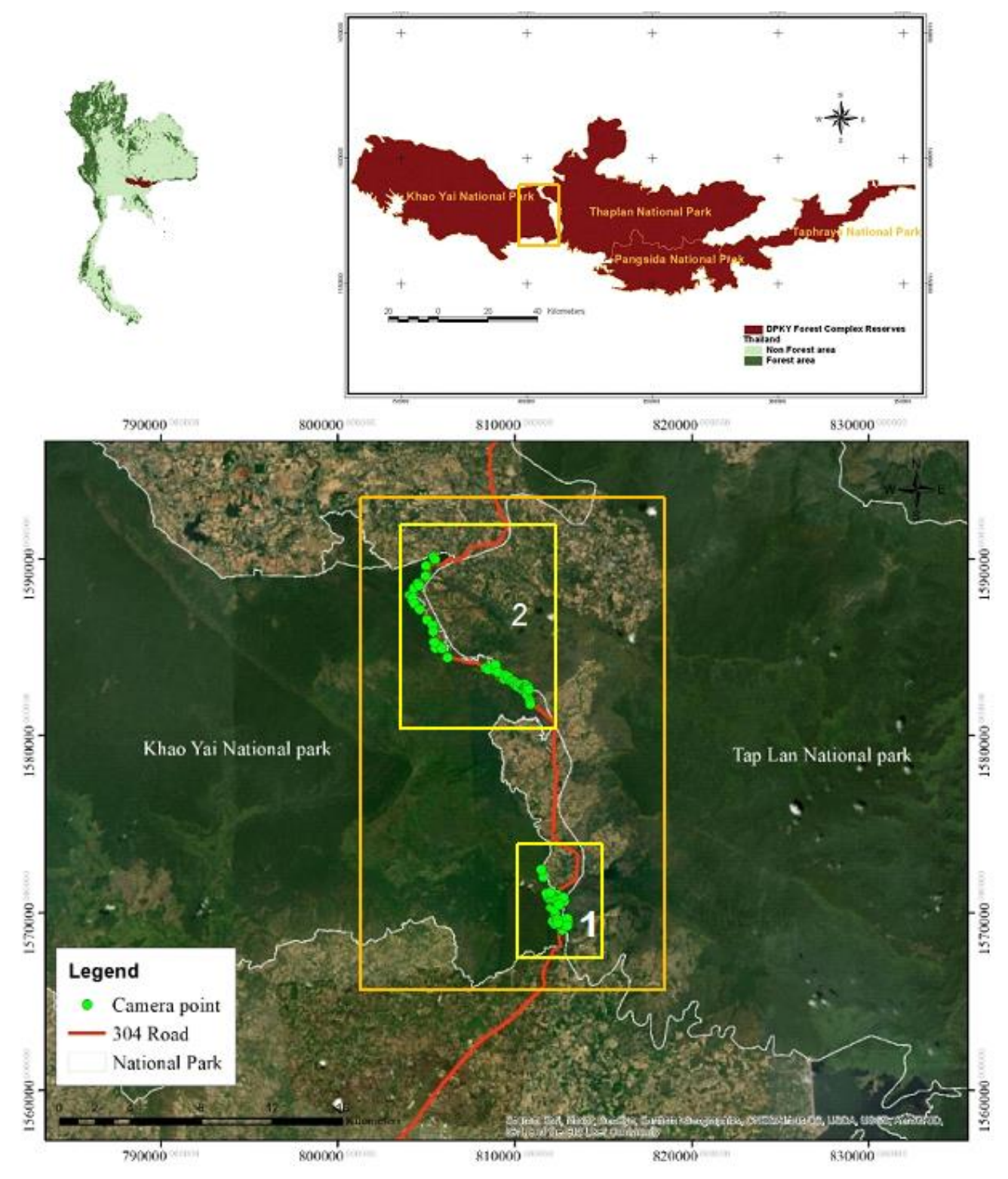

Figure 1. Location of study area and camera traps in Dong Phayayen-Khao Yai Forest Complex in Thailand and the wildlife corridor areas (yellow rectangles), including areas from kilometer marker 26 to 29 (section 1) and kilometer marker 42 to 59 (section 2), covering the areas of both Khao Yai National Park (KYNP) and Thap Lan National Park (TLNP), Prachinburi Province, Thailand. Sources: Google Earth (2021) 


\section{Procedures}

Surveys were conducted along the highway. Camera trap locations were chosen according to the area's suitability, for example, along animal trails or areas where animal tracks were seen. The distance of the camera locations on Highway 304 was between 200-1,000 meters. Generally, each camera trap was approximately installed 500 meters apart from others for the independence of the images, reducing the likelihood of capturing images of the same animal by multiple cameras. In each survey trip, 1015 camera traps were deployed in both National Parks for 1 month in each location and then moved to another suitable location to cover the length of the highway, especially the constructed overpass for the animals to go under, and both sides of the car tunnel for the animals to cross over. The camera traps were placed $30-40 \mathrm{~cm}$ above the ground, 3-4 $\mathrm{m}$ from the targeted area or as appropriate according to the condition of the area. The cameras were set to take three consecutive images every 10 seconds and set to work 24 hours a day with each 24 hours equaling 1 trap day (TEAM network 2008).

The images captured were transferred into the computer and classified using Camera Trap Manager (Zaragozi et al. 2015) and then imported into Microsoft Excel for further data analysis.

\section{Data analysis}

The classification of the wild mammalian species followed Lekagul and McNeely (1988) and for wild bird species observed Lekagul and Round (1991). Only images that could be clearly classified with the date and time shown on the image were identified. The common name, scientific name, taxonomic order and conservation status followed IUCN (2021). This study used the criteria for the independency of animal photographs which include (i) consecutive images of different animals, either the same or different species, (ii) consecutive images of the same animal more than 30 minutes apart and (iii) nonconsecutive images of the same animal of the same species (O’Brien and Kinnaird 2011).

The species diversity was calculated using the ShannonWeiner Index (Krebs 1999) for each wildlife species and the overall wildlife data, based on data on the proportion of images and the number of trap days obtained each year, with the equation presented below:

$$
H=-\sum p_{i} \ln p_{i}
$$

Where:

$p_{i}: \mathrm{S} / \mathrm{N}$,

$\mathrm{S}$ : the number of individuals of one species,

$\mathrm{N}$ : the total number of all individuals in the sample,

In : the logarithm to the base e.

If $\mathrm{H}^{\prime} \leq 1$, it is classified as low diversity, $1<\mathrm{H}^{\prime} \leq 3$ as moderate diversity and $\mathrm{H}^{\prime} \geq 3$ as high diversity (Ulfah et al. 2019).

The evenness index is a measure of how similar the abundances of different species are in the community (Pielou 1966; Kvalseth 2015). It is calculated as:
Species Evenness $=\mathrm{H} / \operatorname{Ln}((\mathrm{s}-1) / \operatorname{Ln}(\mathrm{n}))$

Where:

$\mathrm{s}$ : Number of Species Recorded

$\mathrm{n}$ : Total Number of Individuals in the Sample

H : Shannon's Diversity Index

Evenness index of $0<\mathrm{E} \leq 0.4$ is classified as a depressed community, $0.4<\mathrm{E} \leq 0.6$ as an unstable community, and if $0.6<\mathrm{E} \leq 1$ as a stable community (Herawati et al. 2019).

The calculation results were used as an index to measure the diversity of the wildlife. The diversity index of the wildlife was then compared between the years 2017 and 2018, which is the period before the opening of the wildlife corridor and 2020 to 2021, which is the period after the wildlife corridors were opened.

The relative abundance index (RAI) of each wildlife species recorded by the camera traps was calculated using the ratio between the presence of the image and the number of the total trap days, which is a method widely used, e.g., Ouboter and Kadosoe (2016), Steinbeiser et al. (2019). The equation is as follows,

$$
\text { Relative abundance }(\%)=\frac{\text { trap success } \times 100}{\text { trap nights }}
$$

The \%RAIs of wildlife species were compared between years 2017 and 2018, which is the period before the wildlife corridor and years 2020 to 2021, which is after the wildlife corridors were opened, using the Mann-Whitney U test at a significance level of $p<0.05$.

The wildlife activity pattern was studied by dividing the time into 24 hours. The activity time of each species was classified from the number of images, which was divided into 2 periods: daytime, between 06:01-17:59 hrs and nighttime between 18:00-06:00 hrs (Azlan 2009). The percentages of the number of images for both time periods for each species were calculated and the animals were classified into 5 groups following the method of van Schaik and Griffiths (1996). If the number of images during the night was more than $85 \%$, the animals were classified as strongly nocturnal. If the number of images during the night was between $61-84 \%$, the animals were classified as primarily nocturnal. If the number of images during the night was between $40-60 \%$, the animals were classified as cathemeral. If the number of images during the day was between $61-84 \%$, the animals were classified as primarily diurnal, and if the number of images during the day was more than $85 \%$, the animals were classified as strongly daily.

The activity pattern of wildlife from the summary of the activity period from the camera trap images classified by species and the overall data of each animal group were calculated, and with ORIANA version 4.02 (Kovach Computing Services 2019), the Mean Vector $(\mu)$ was calculated at $95 \%$ Confidence Interval $(-/+)$ for $\mu$ and the Circular Variance to compare the time of presence in each period.

The analysis of the suitable habitat of every wildlife species recorded by camera traps was performed using 
MaxEnt. MaxEnt only needs the presence data of the interesting species (Phillips and Dudik 2008) based on the relation with environmental factors that affect habitat suitability (Elith et al. 2006; Merow et al. 2013) with methods described below.

The geolocation data of the presence of every wildlife species obtained from the camera traps were imported to be used to find relationships with other environmental factors. Wildlife was classified as herbivorous mammals or not carnivores, carnivorous mammals, birds and reptiles. The environmental factors were divided into biological environmental factors and physical environmental factors (10), including elevation, water sources both natural and artificial, villages, conditions of utilization of the area various forest types and agricultural areas, and transportation routes and wildlife crossings. All spatial data were converted into raster data for analysis. There were two data types including continuous data, i.e., elevation layer, permanent river (Lam Phraya Than in Khao Yai National Park that flows smoothly along the constructed wildlife corridor), transportation routes, community sites and constructed wildlife corridors, and category data which is the type of land use that includes plant society and agricultural areas. Models of distribution and likelihood of presence in the habitat were then created according to the environmental factors of each wildlife species by dividing the data set into two data sets with a ratio of $75: 25,75 \%$ of the data were used for testing in the MaxEnt program and $25 \%$ of the data were used for verification. The equal training sensitivity and specificity were then tested using the criteria of the logistic threshold of animal presence and absence and the percentage contribution for each of the environmental factors obtained from testing the model, which is the result of the analysis of the relationship between the coordinates of the wildlife presence and the primary environment (Phillips and Dudik 2008).

\section{RESULTS AND DISCUSSION}

\section{Species diversity}

From the deployment of camera traps in 99 locations for 12,945 trap nights, a total of 27,494 images were recorded. A total number of 51 wildlife species from 30 families in 14 orders were recorded including 30 species of mammals from 15 families in 5 orders, 17 bird species from 12 families in 7 orders and 4 species of reptiles from 3 families in 2 orders. The mammalian species in the order Carnivora comprised 4 families including family Mustelidae, there was Greater Hog Badger (Arctonyx collaris); family Ursidae with 2 species, Asiatic Black Bear (Ursus thibetanus) and Sun Bear (Helarctos malayanus); family Herpestidae with 2 species, Javan Mongoose )Herpestes javanicus), and Crab-eating Mongoose (Herpestes urva); family Viverridae recorded 4 species including Common Palm Civet (Paradoxurus hermaphroditus), Small Indian Civet (Viverricula indica), Large Indian Civet (Viverra zibetha) and Large-spotted Civet )Viverra megaspila); family Canidae had 2 species including Dhole (Cuon alpinus) and Golden Jackal )Canis aureus); family Felidae recorded 4 species including Leopard Cat (Prionailurus bengalensis), Asiatic Golden Cat (Catopuma temminckii), Clouded Leopard (Neofelis nebulosa) and Fishing Cat (Prionailurus viverrinus). Mammals in the order Artiodactyla comprised 4 families including family Bovidae with 2 species, which are Gaur (Bos gaurus) and Mainland Serow (Capricornis sumatraensis); family Elephantidae including Asian Elephant )Elephas maximus); family Cervidae with 3 species including Sambar (Rusa unicolor), Northern Red Muntjac (Muntiacus vaginalis) and Lesser Oriental Chevrotain (Tragulus kanchil); family Suidae with Wild Boar (Sus scrofa).

Order Primates comprised family Cercopithecidae with 1 species, the Northern pig-tailed Macaque (Macaca leonine). Order Pholidota included 1 species, the Sunda Pangolin (Manis javanica) from the family Manidae. Order Rodentia found 3 families including family Hystricidae with the Malayan Porcupine (Hystrix brachyura); family Sciuridae found 4 species including Berdmore's Squirrel (Menetes berdmorei), Grey-bellied Squirrel (Callosciurus caniceps), Variable Squirrel (Callosciurus finlaysonii) and Northern Treeshrew (Tupaia belangeri), etc. The wild birds recorded were from 8 orders from 12 families. Five families in the order Passeriformes including family Vangidae with 1 species, the Large Woodshrike (Tephrodornis gularis) and family Dicruridae with 1 species, which is the Greater Racquet-tailed Drongo (Dicrurus paradiseus), family Cettiidae included the Chestnut-crowned Bush Warbler (Cettia major), family Muscicapidae included the white-rumped Shama (Kittacincla malabarica), family Pittidae included the Blue-winged Pitta (Pitta moluccensis), etc. The wild birds in order Pelecaniformes include 2 species from family Ardeidae, which are Chinese Pond-heron (Ardeola bacchus) and Malay Night-heron (Gorsachius melanolophus).

Order Caprimulgiformes found 2 families including family Caprimulgidae containing 1 species, Large-tailed Nightjar (Caprimulgus macrurus) and family Cuculidae including the Coral-billed Ground-cuckoo (Carpococcyx renauldi). One family from the order Columbiformes was recorded which family Columbidae was with 4 species including Grey-capped Emerald Dove (Chalcophaps indica), Eastern Spotted Dove (Spilopelia chinensis), Red Turtle-dove (Streptopelia tranquebarica) and Rock Dove (Columba livia). Order Galliformes had 1 family, Phasianidae with 2 species, Red Junglefowl (Gallus gallus) and Siamese Fireback (Lophura diardi), etc.

The camera traps also recorded images of reptiles from 2 orders including order Testudines with the Asian Giant tortoise (Manouria emys) from the family Testudinidae and Order Squamata recorded 2 families including family Agamidae containing the Northern Forest Crested Lizard (Calotes emma) and family Varanidae with 2 species, the Bengal Monitor (Varanus bengalensis) and the Common Water Monitor (Varanus salvator). The number of images for each season and the conservation status of the species followed IUCN (2021) as shown in Table 1. 
Table 1. Wildlife species were recorded along the Highway 304 between Khao Yai National Park and Thap Lan National Park following the taxonomic order, the conservation status and the number of independent wildlife images captured from camera traps from September 2018 to May 2021. The captured images were collated across three periods: before once opened and after the opening of the wildlife corridors from 99 locations, 12,945 trap nights with a total of 27,494 images

\begin{tabular}{|c|c|c|c|c|c|c|c|c|c|c|c|c|c|c|}
\hline \multirow{5}{*}{ Order/Family/common name } & \multicolumn{5}{|c|}{ Before opening } & \multirow{2}{*}{\multicolumn{2}{|c|}{$\begin{array}{c}\text { Year opened } \\
2019\end{array}$}} & \multicolumn{4}{|c|}{ After opening } & \multirow{4}{*}{\multicolumn{2}{|c|}{$\begin{array}{c}\text { Combined data } \\
2017-2021 \\
99 \\
12,945 \\
\end{array}$}} & \multirow{5}{*}{$\begin{array}{l}\text { Status } \\
\text { IUCN } \\
(\mathbf{2 0 2 1})\end{array}$} \\
\hline & \multirow{4}{*}{$\begin{array}{c}\text { Year } \\
\begin{array}{c}\text { No. of camera locations } \\
\text { Number of trap days }\end{array} \\
\text { Scientific name } \\
\end{array}$} & \multirow{3}{*}{\multicolumn{2}{|c|}{$\begin{array}{c}2017 \\
17 \\
1,377\end{array}$}} & \multirow{3}{*}{\multicolumn{2}{|c|}{\begin{tabular}{|c|}
2018 \\
19 \\
2,364 \\
\end{tabular}}} & & & \multirow{3}{*}{\multicolumn{2}{|c|}{$\begin{array}{c}2020 \\
31 \\
3,890\end{array}$}} & \multirow{3}{*}{\multicolumn{2}{|c|}{$\begin{array}{c}2021 \\
25 \\
1,960\end{array}$}} & & & \\
\hline & & & & & & \multirow{2}{*}{\multicolumn{2}{|c|}{$\begin{array}{c}28 \\
3,354 \\
\end{array}$}} & & & & & & & \\
\hline & & & & & & & & & & & & & & \\
\hline & & Events & RAI & Events & RAI & Events & RAI & Events & RAI & Events & RAI & Events & RAI & \\
\hline \multirow{2}{*}{\multicolumn{15}{|c|}{ Mammal }} \\
\hline \multicolumn{8}{|l|}{ Order Carnivora } & & & & & & & \\
\hline \multicolumn{15}{|l|}{ Family Mustelidae } \\
\hline Greater hog badger & Arctonyx collaris & 14 & 1.02 & 100 & 4.23 & 171 & 5.09 & 65 & 1.67 & 29 & 1.48 & 379 & 2.93 & VU \\
\hline \multicolumn{15}{|l|}{ Family Ursidae } \\
\hline Asiatic Black Bear & Ursus thibetanus & 0 & 0 & 22 & 0.93 & 3 & 0.09 & 22 & 0.57 & 0 & 0 & 47 & 0.36 & VU \\
\hline Sun Bear & Helarctos malayanus & 0 & 0 & 1 & 0.04 & 1 & 0.03 & 1 & 0.02 & 11 & 0.05 & 14 & 0.11 & VU \\
\hline \multicolumn{15}{|l|}{ Family Herpestidae } \\
\hline Javan Mongoose & Herpestes javanicus & 0 & 0 & 36 & 1.52 & 3 & 0.09 & 16 & 0.41 & 0 & 0 & 55 & 0.36 & $\mathrm{LC}$ \\
\hline Crab-eating mongoose & Herpestes urva & 0 & 0 & 0 & 0 & 13 & 0 & 1 & 0 & 1 & 0.05 & 15 & 0.12 & $\mathrm{LC}$ \\
\hline \multicolumn{15}{|l|}{ Family Viverridae } \\
\hline Common Palm Civet & Paradoxurus hermaphroditus & 37 & 2.68 & 129 & 5.46 & 135 & 4.02 & 221 & 5.68 & 45 & 2.30 & 567 & 4.38 & $\mathrm{LC}$ \\
\hline Small Indian Civet & Viverricula indica & 23 & 1.67 & 94 & 3.97 & 16 & 0.48 & 25 & 0.64 & 36 & 0.18 & 194 & 1.50 & $\mathrm{LC}$ \\
\hline Large Indian Civet & Viverra zibetha & 3 & 0.22 & 15 & 0.63 & 7 & 0.21 & 4 & 0.10 & 2 & 0.10 & 30 & 0.23 & $\mathrm{LC}$ \\
\hline Large-spotted Civet & viverra megaspila & 0 & 0 & 21 & 0.88 & 2 & 0.06 & 2 & 0.05 & 0 & 0 & 25 & 0.18 & $\mathrm{EN}$ \\
\hline \multicolumn{15}{|l|}{ Family Canidae } \\
\hline Dhole & Cuon alpinus & 3 & 0.22 & 21 & 0.88 & 29 & 0.86 & 25 & 0.64 & 11 & 0.56 & 89 & 0.69 & EN \\
\hline Golden Jackal & Canis aureus & 53 & 3.85 & 120 & 5.08 & 7 & 0.21 & 13 & 0.33 & 11 & 0.56 & 204 & 1.61 & $\mathrm{LC}$ \\
\hline \multicolumn{15}{|l|}{ Family Felidae } \\
\hline Leopard Cat & Prionailurus bengalensis & 10 & 0.73 & 21 & 0.89 & 11 & 0.33 & 148 & 3.80 & 14 & 0.71 & 204 & 1.58 & $\mathrm{LC}$ \\
\hline Asiatic Golden Cat & Catopuma temminckii & 0 & 0 & 0 & 0 & 1 & 0.03 & 0 & 0 & 4 & 0.20 & 5 & 0.04 & NT \\
\hline Clouded Leopard & Neofelis nebulosa & 0 & 0 & 0 & 0 & 0 & 0 & 3 & 0.08 & 3 & 0.15 & 6 & 0.05 & VU \\
\hline Fishing cat & Prionailurus viverrinus & 0 & 0 & 0 & 0 & 0 & 0 & 0 & 0 & 4 & 0.20 & 4 & 0.03 & VU \\
\hline \multicolumn{15}{|l|}{ Order Artiodactyla } \\
\hline \multicolumn{15}{|l|}{ Family Bovidae } \\
\hline Gaur & Bos gaurus & 135 & 9.80 & 152 & 6.43 & 315 & 9.39 & 900 & 23.13 & 325 & 16.58 & 1827 & 14.11 & VU \\
\hline Mainland Serow & Capricornis sumatraensis & 15 & 1.09 & 225 & 9.52 & 164 & 4.89 & 122 & 3.13 & 46 & 2.35 & 572 & 0.44 & VU \\
\hline \multicolumn{15}{|l|}{ Family Elephantidae } \\
\hline Asian elephant & Elephas maximus & 0 & 0 & 0 & 0 & 27 & 0.80 & 62 & 1.59 & 40 & 2.04 & 129 & 1.00 & EN \\
\hline Family Cervidae & & & & & & & & & & & & & & \\
\hline Sambar deer & Rusa unicolor & 3167 & 229.99 & 2614 & 11.06 & 1527 & 45.53 & 2829 & 72.72 & 1368 & 69.80 & 11505 & 88.87 & VU \\
\hline Northern Red Muntjac & Muntiacus vaginalis & 130 & 5.95 & 445 & 18.82 & 390 & 11.63 & 685 & 17.61 & 142 & 7.24 & 1792 & 13.84 & $\mathrm{LC}$ \\
\hline Lesser Oriental Chevrotain & Tragulus kanchil & 0 & 0 & 87 & 3.68 & 39 & 1.16 & 9 & 0.23 & 2 & 0.10 & 137 & 1.05 & $\mathrm{LC}$ \\
\hline
\end{tabular}




\begin{tabular}{|c|c|c|c|c|c|c|c|c|c|c|c|c|c|c|}
\hline $\begin{array}{l}\text { Family Suidae } \\
\text { Wild boar } \\
\text { Order Primates }\end{array}$ & Sus scrofa & 679 & 49.31 & 684 & 28.93 & 790 & 23.55 & 1120 & 28.79 & 631 & 32.19 & 3904 & 30.15 & LC \\
\hline \multicolumn{15}{|l|}{$\begin{array}{l}\text { Order Primates } \\
\text { Family Cercopithecidae }\end{array}$} \\
\hline $\begin{array}{l}\text { Northern Pig-tailed Macaque } \\
\text { Order Pholidota }\end{array}$ & Macaca leonine & 135 & 9.80 & 797 & 33.71 & 405 & 12.07 & 876 & 22.52 & 68 & 3.47 & 2421 & 18.70 & VU \\
\hline \multicolumn{15}{|l|}{ Family Manidae } \\
\hline $\begin{array}{l}\text { Sunda Pangolin } \\
\text { Order Rodentia }\end{array}$ & \multicolumn{12}{|c|}{ Order Rodentia } & 0.05 & $\mathrm{CR}$ \\
\hline \multicolumn{15}{|l|}{ Family Hystricidae } \\
\hline Berdmore's Squirrel & Menetes berdmorei & 7 & 0.51 & 8 & 0.33 & 32 & 0.95 & 11 & 0.28 & 9 & 0.45 & 67 & 0.52 & LC \\
\hline Grey-bellied Squirrel & Callosciurus caniceps & 10 & 0.72 & 81 & 3.42 & 88 & 2.62 & 91 & 2.33 & 26 & 1.33 & 296 & 2.29 & LC \\
\hline Variable Squirrel & Callosciurus finlaysonii & 7 & 0.51 & 101 & 4.27 & 10 & 0.29 & 6 & 0.15 & 12 & 0.61 & 136 & 1.05 & $\mathrm{LC}$ \\
\hline Northern treeshrew & Tupaia belangeri & 0 & 0 & 0 & 0 & 0 & 0 & 3 & 0.08 & 2 & 0.10 & 5 & 0.04 & - \\
\hline \multicolumn{15}{|l|}{ Family Muridae } \\
\hline Rattus spp. & Rattus spp. & 12 & 0.87 & 189 & 7.99 & 133 & 3.96 & 140 & 3.60 & 15 & 0.77 & 489 & 3.78 & - \\
\hline \multicolumn{15}{|l|}{ Aves } \\
\hline \multicolumn{15}{|l|}{ Order Cuculiformes } \\
\hline \multicolumn{15}{|l|}{ Family Cuculidae } \\
\hline $\begin{array}{c}\text { Greater coucal } \\
\text { Order Accipitriformes }\end{array}$ & Centropus sinensis & 0 & 0 & 0 & 0 & 0 & 0 & 4 & 0.10 & 7 & 0.36 & 11 & 0.08 & LC \\
\hline \multicolumn{15}{|l|}{ Family Accipitridae } \\
\hline Shikra & Accipiter badius & 3 & 0.22 & 0 & 0 & 0 & 0 & 0 & 0 & 0 & 0 & 3 & 0.02 & LC \\
\hline \multicolumn{15}{|l|}{ Order Pelecaniformes } \\
\hline Chinese pond-heron & Ardeola bacchus & 0 & 0 & 9 & 0.38 & 3 & 0.09 & 10 & 0.26 & 5 & 0.26 & 27 & 0.21 & LC \\
\hline Malay Night-heron & Gorsachius melanolophus & 0 & 0 & 96 & 4.06 & 0 & 0 & 3 & 0.08 & 2 & 0.10 & 101 & 0.78 & LC \\
\hline \multicolumn{15}{|l|}{ Order Caprimulgiformes } \\
\hline \multicolumn{15}{|l|}{ Family Caprimulgidae } \\
\hline $\begin{array}{l}\text { Large-tailed Nightjar } \\
\text { Family Cuculidae }\end{array}$ & Caprimulgus macrurus & 0 & 0 & 3 & 0.13 & 0 & 0 & 0 & 0 & 345 & 17.60 & 348 & 2.69 & LC \\
\hline $\begin{array}{l}\text { Coral-billed Ground-cuckoo } \\
\text { Order Galliformes }\end{array}$ & Carpococcyx renauldi & 0 & 0 & 17 & 0.72 & 2 & 0.06 & 0 & 0 & 3 & 0.15 & 22 & 0.17 & VU \\
\hline \multicolumn{15}{|l|}{ Family Phasianidae } \\
\hline Red Junglefowl & Gallus gallus & 55 & 3.99 & 94 & 3.97 & 131 & 3.91 & 153 & 3.93 & 59 & 3.01 & 492 & 3.80 & LC \\
\hline Siamese Fire back & Lophura diardi & 20 & 1.45 & 235 & 9.94 & 128 & 3.82 & 129 & 3.32 & 33 & 1.68 & 545 & 4.21 & LC \\
\hline \multicolumn{15}{|l|}{ Order Columbiformes } \\
\hline \multicolumn{15}{|l|}{ Family Columbidae } \\
\hline Grey-capped Emerald Dove & Chalcophaps indica & 0 & 0 & 9 & 0.38 & 0 & 0 & 0 & 0 & 2 & 0.10 & 11 & 0.08 & LC \\
\hline Eastern Spotted Dove & Spilopelia chinensis & 0 & 0 & 0 & 0 & 219 & 6.53 & 4 & 0.01 & 7 & 0.35 & 230 & 1.78 & LC \\
\hline Red Turtle-dove & Streptopelia tranquebarica & 0 & 0 & 0 & 0 & 0 & 0 & 0 & 0 & 0 & 0 & 1 & 0.01 & $\mathrm{LC}$ \\
\hline Rock Dove & Columba livia & 0 & 0 & 0 & 0 & 19 & 0.57 & 0 & 0 & 0 & 0 & 19 & 0.13 & LC \\
\hline
\end{tabular}




\begin{tabular}{|c|c|c|c|c|c|c|c|c|c|c|c|c|c|c|}
\hline \multicolumn{15}{|l|}{ Order Passeriformes } \\
\hline Large woodshrike & Tephrodornis gularis & 0 & 0 & 0 & 0 & 1 & 0.03 & 0 & 0 & 1 & 0.05 & 2 & 0.01 & $\mathrm{LC}$ \\
\hline Family Cettiidae & & & & & & & & & & & & & & \\
\hline Chestnut-crowned bush warbler & Cettia major & 0 & 0 & 3 & 0 & 0 & 0 & 0 & 0 & 0 & 0 & 3 & 0.02 & $\mathrm{LC}$ \\
\hline Family Muscicapidae & & & & & & & & & & & & & & \\
\hline White-rumped Shama & Kittacincla malabarica & 3 & 0.22 & 3 & 0.13 & 0 & 0 & 0 & 0 & 0 & 0 & 6 & 0.04 & $\mathrm{LC}$ \\
\hline Family Pittidae & & & & & & & & & & & & & & \\
\hline Blue-winged pitta & Pitta moluccensis & 0 & 0 & 21 & 0.09 & 0 & 0 & 0 & 0 & 0 & 0 & 21 & 0.16 & $\mathrm{LC}$ \\
\hline Family Dicruridae & & & & & & & & & & & & & & \\
\hline Greater Racquet-tailed Drongo & Dicrurus paradiseus & 0 & 0 & 0 & 0 & 0 & 0 & 0 & 0 & 1 & 0.05 & 1 & 0.01 & $\mathrm{LC}$ \\
\hline $\begin{array}{l}\text { Reptile } \\
\text { Order Testudines } \\
\text { Family Testudinidae }\end{array}$ & & & & & & & & & & & & & & \\
\hline \begin{tabular}{l}
\multicolumn{1}{l}{ Asian forest tortoise } \\
Order Squamata \\
Family Agamidae
\end{tabular} & Manouria emys & 3 & 0.22 & 0 & 0 & 0 & 0 & 0 & 0 & 0 & 0 & 3 & 0.02 & $\mathrm{CR}$ \\
\hline $\begin{array}{l}\text { Northern forest crested lizard } \\
\text { Family Varanidae }\end{array}$ & Calotes emma & 0 & 0 & 3 & 0.13 & 0 & 0 & 0 & 0 & 0 & 0 & 3 & 0.02 & - \\
\hline Bengal monitor & Varanus bengalensis & 0 & 0 & 3 & 0.13 & 0 & 0 & 0 & 0 & 0 & 0 & 3 & 0.02 & $\mathrm{LC}$ \\
\hline Common water Monitor & $\begin{array}{l}\text { Varanus salvator } \\
\text { Total }\end{array}$ & $\begin{array}{c}0 \\
4,558\end{array}$ & 0 & $\begin{array}{c}3 \\
6,559\end{array}$ & 0.13 & $\begin{array}{c}15 \\
5,033\end{array}$ & 0.44 & $\begin{array}{c}0 \\
78,43\end{array}$ & 0 & $\begin{array}{c}0 \\
3,361\end{array}$ & 0 & $\begin{array}{c}18 \\
27,494\end{array}$ & 0.13 & $\mathrm{LC}$ \\
\hline
\end{tabular}


Regarding the diversity index across the observed periods, it was found that in 2017 the diversity index of both mammals and birds and the overall species was the lowest. It then increased from 2018 to 2021, similar to the evenness index of wild mammals and birds that was between $0-1$. Lower values mean low distribution in the area, whereas the high values mean a large distribution. From Table 2, the combined data showed that the overall wildlife evenness index was similar during 2018-2021, while in 2017 the value was low. This was caused by the installation of camera traps in the early stages of the study that did not cover the whole area, while in 2018 the deployment of the camera traps covered more of the area. The evenness of the species shows the distribution of the abundance between species within the community. The high evenness index means that the abundance of the wildlife in the community is similar (Zhang et al. 2012).

Regarding the conservation status of the wildlife according to the IUCN Red List, we found 2 species that are categorized as Critically Endangered (IUCN 2021), which are the Sunda Pangolin (Manis javanica) and the Asian Giant Tortoise (Manouria emys). Three species are categorized as Endangered including Large-spotted Civet (Viverra megaspila), Dhole (Cuon alpinus) and Asian Elephant (Elephas maximus). Ten species are Vulnerable including Greater Hog Badger (Arctonyx collaris), Asiatic Black Bear (Ursus thibetanus), Sun Bear (Helarctos malayanus), Clouded Leopard (Neofelis nebulosa), Fishing Cat (Prionailurus viverrinus), Gaur (Bos gaurus), Mainland Serow (Capricornis sumatraensis), Sambar Deer (Rusa unicolor), Northern Pig-tailed macaque (Macaca leonine) and Coral-billed Ground-cuckoo (Carpococcyx renauldi). One Near-Threatened species is the Asiatic Golden Cat (Catopuma temminckii) and 32 species that are Least Concern for example the Javan Mongoose (Herpestes javanicus), Crab-eating Mongoose (Herpestes urva), Common Palm Civet (Paradoxurus hermaphroditus), Small Indian Civet (Viverricula indica), Large Indian Civet (Viverra zibetha), Golden Jackal (Canis aureus), Leopard Cat (Prionailurus bengalensis), Northern Red Muntjac (Muntiacus vaginalis), Lesser Oriental Chevrotain (Tragulus kanchil), Wild Boar (Sus scrofa), Malayan Porcupine (Hystrix brachyura), etc. Details are shown in Table 1.
Regarding the abundance of the herbivorous wildlife, the predominant species in the study area was the Sambar Deer with $88.87 \%$, followed by Wild Boar (30.15\%), Northern Pig-tailed Macaque (18.7\%), Gaur (14.11\%), Northern Red Muntjac (13.84\%), Malayan Porcupine (3.86\%), etc. In the carnivorous group, the species with the highest abundance was the Common Palm Civet at $4.38 \%$, followed by Greater Hog Badger $(2.93 \%)$, Golden Jackal (1.61\%), Leopard Cat (1.58\%), Small Indian Civet $(1.50 \%)$, Dhole $(0.69 \%)$, etc. For ground foraging birds, the Siamese fireback had the highest abundance at $4.21 \%$, followed by the Red Junglefowl (3.8\%), Large-tailed Nightjar (2.69\%), Eastern Spotted Dove (1.78\%), Malay Night-heron $(0.78 \%)$, Chinese Pond-heron $(0.21 \%)$, etc. (Table 1)

Results from the test on the difference in the abundance of wildlife before and after the opening of the wildlife corridors indicate no difference in the abundance of wildlife (Mann-Whitney U-test $=-0.07709, \mathrm{P}=0.94$ ). Furthermore, it was found that there was no difference in the average abundance of wildlife in the study area before the use of the wildlife corridors in 2017-2018 and during the opening in $2019(Z=0.77301 ; P=0.4413)$. There was no difference in the average abundance after opening the wildlife corridors in 2020-2021 and when they first opened in $2019(\mathrm{Z}=0.64585, \mathrm{P}=0.5157)$. Furthermore, the Shannon-Weiner index of all the wildlife recorded during the total length of the study was 1.98 and the evenness index was 0.88 . Therefore, there was little difference in the values between the years, as shown in Table 2 .

\section{Activity pattern and period}

Study results showed that in the study area along the Highway 304 in part between the 2 National Parks, wild animals were found engaged in activities throughout the day, alternating between species. When considering only the wildlife that had more than 30 images recorded, it was found that 8 species of wildlife had activity patterns that were strongly nocturnal including Common Palm Civet, Malayan Porcupine, Greater Hog Badger, Leopard Cat, Small Indian Civet, Large Indian Civet, Large-spotted Civet, Large-tailed Nightjar as well as rat species that were recorded as Rattus sp.

Table 2. Biodiversity and evenness index of mammals and wild birds that were recorded by camera traps along the Highway 304 between Khao Yai National Park and Thap Lan National Park during 2017-2021 and combined data analysis

\begin{tabular}{|c|c|c|c|c|c|c|}
\hline \multirow{2}{*}{ Year } & \multicolumn{2}{|c|}{ Before opening } & \multirow{2}{*}{$\begin{array}{c}\text { Year opened } \\
2019 \\
\end{array}$} & \multicolumn{2}{|c|}{ After opening } & \multirow{2}{*}{$\begin{array}{c}\text { Combined } \\
\text { data }\end{array}$} \\
\hline & 2017 & 2018 & & 2020 & 2021 & \\
\hline \multicolumn{7}{|l|}{ Terrestrial Mammal } \\
\hline Shannon-Weiner index & 0.3037 & 2.251 & 1.991 & 1.861 & 1.935 & 1.753 \\
\hline Evenness index & 0.1843 & 0.1705 & 1.1197 & 1.0909 & 1.0983 & 1.0277 \\
\hline \multicolumn{7}{|l|}{ Terrestrial Bird } \\
\hline Shannon-Weiner index & 0.4988 & 1.309 & 0.2496 & 0.9706 & 1.553 & 1.713 \\
\hline Evenness index & 0.2267 & 0.7797 & 0.1405 & 0.4714 & 0.9586 & 0.9534 \\
\hline \multicolumn{7}{|l|}{ Combined data } \\
\hline Shannon-Weiner index & 0.8157 & 2.501 & 2.167 & 1.924 & 2.238 & 1.98 \\
\hline Evenness index & 0.3784 & 1.1027 & 0.9418 & 0.8577 & 0.983 & 0.8852 \\
\hline
\end{tabular}


Eight species were strongly diurnal including Greybellied Squirrel, Dhole, Berdmore's Squirrel, Siamese Fireback, Red Junglefowl, Eastern Spotted Dove, Malay night-heron and Javan Mongoose. There were 4 species that were mostly nocturnal including Sambar Deer, Gaur, Mainland Serow and Golden Jackal. Four species mainly were diurnal including Northern Pig-tailed Macaque,
Lesser Oriental Chevrotain, Variable Squirrel and Asian Elephant, and 3 species that were cathemeral including Wild Boar, Northern Red Muntjac and Asiatic Black Bear. The activity period and the confidence interval of the activity period of the recorded wildlife species are shown in Table 3.

Table 3. Time and activity pattern of wildlife found in the study area along the Highway 304 between Khao Yai National Park and Thap Larn National Park during 2017 to 2021

\begin{tabular}{|c|c|c|c|c|c|}
\hline Common name & $\begin{array}{c}\text { Encounter rate } \\
\text { of pictures }\end{array}$ & $\begin{array}{l}\text { Mean vector } \\
\text { (hour) }\end{array}$ & $\begin{array}{c}\text { Circular } \\
\text { variance (hour) }\end{array}$ & $\begin{array}{c}\text { \% of day } \\
\text { time }\end{array}$ & Type \\
\hline Common palm civet & 576 & $23: 39$ & $00: 09$ & 0.69 & SN \\
\hline Malayan porcupine & 500 & $01: 29$ & $00: 11$ & 4.8 & SN \\
\hline Rattus spp. & 485 & $00: 53$ & 00:09 & 2.47 & SN \\
\hline Greater hog badger & 377 & $01: 32$ & 05:08 & 22.28 & SN \\
\hline Large-tailed nightjar & 348 & $23: 46$ & $00: 13$ & 1.72 & SN \\
\hline Leopard cat & 204 & 03:22 & 00:20 & 13.72 & SN \\
\hline Small indian civet & 194 & $00: 22$ & $00: 18$ & 11.34 & $\mathrm{SN}$ \\
\hline Large indian civet & 30 & 23:07 & $00: 44$ & 0 & SN \\
\hline Large-spotted civet & 25 & $00: 58$ & $00: 42$ & 12 & SN \\
\hline Siamese fireback & 544 & $10: 11$ & $00: 10$ & 100 & SD \\
\hline Red junglefowl & 492 & 11:08 & 00:09 & 100 & SD \\
\hline Grey-bellied squirrel & 264 & $12: 23$ & $00: 13$ & 92.04 & SD \\
\hline Dhole & 49 & $11: 23$ & $00: 30$ & 91.83 & SD \\
\hline Eastern spotted dove & 221 & $12: 10$ & $00: 31$ & 100 & SD \\
\hline Malay night-heron & 101 & $08: 58$ & $00: 30$ & 82.18 & SD \\
\hline Berdmore's squirrel & 67 & $10: 26$ & $00: 29$ & 91.04 & SD \\
\hline Javan mongoose & 55 & $12: 59$ & $00: 24$ & 94.54 & SD \\
\hline Sambar deer & 11,500 & $22: 38$ & 00:06 & 28.69 & $\mathrm{MN}$ \\
\hline Gaur & 1,826 & $22: 48$ & $00: 16$ & 35.6 & $\mathrm{MN}$ \\
\hline Mainland serow & 572 & $00: 22$ & $00: 19$ & 21.5 & $\mathrm{MN}$ \\
\hline Golden jackal & 209 & $02: 18$ & $00: 29$ & 33.97 & MN \\
\hline Northern pig-tailed macaque & 2418 & $12: 19$ & 00:05 & 84.78 & MD \\
\hline Lesser oriental chevrotain & 137 & $08: 25$ & $00: 20$ & 81.02 & MD \\
\hline Variable squirrel & 136 & $13: 44$ & $00: 42$ & 83.82 & MD \\
\hline Asian elephant & 129 & 08:09 & $00: 24$ & 82.95 & MD \\
\hline Wild boar & 3903 & $00: 29$ & $00: 25$ & 42.35 & $\mathrm{CM}$ \\
\hline Northern red muntjac & 1785 & $11: 35$ & $00: 20$ & 57.03 & $\mathrm{CM}$ \\
\hline Asiatic black bear & 47 & $20: 02$ & 01:06 & 46.8 & $\mathrm{CM}$ \\
\hline Chinese pond-heron & 27 & 13:01 & $00: 14$ & 100 & Not classified \\
\hline Coral-billed ground-cuckoo & 22 & $10: 05$ & $02: 10$ & 100 & Not classified \\
\hline Blue-winged pitta & 21 & $11: 04$ & $01: 25$ & 100 & Not classified \\
\hline Rock dove & 19 & $09: 58$ & $00: 11$ & 100 & Not classified \\
\hline Common water monitor & 18 & $13: 42$ & $00: 24$ & 100 & Not classified \\
\hline Crab-eating mongoose & 15 & $10: 21$ & $00: 53$ & 100 & Not classified \\
\hline Sun bear & 14 & 23:07 & 01:12 & 21.42 & Not classified \\
\hline Greater coucal & 11 & $11: 2$ & $00: 38$ & 100 & Not classified \\
\hline Grey-capped emerald dove & 11 & $12: 05$ & $00: 14$ & 100 & Not classified \\
\hline Sunda pangolin & 6 & $05: 19$ & 00:00 & 0 & Not classified \\
\hline White-rumped shama & 6 & $10: 37$ & 00:03 & 100 & Not classified \\
\hline Clouded leopard & 6 & $04: 34$ & $00: 42$ & 0 & Not classified \\
\hline Northern treeshrew & 5 & $09: 20$ & $00: 14$ & 100 & Not classified \\
\hline Asiatic golden cat & 5 & $06: 42$ & 00:00 & 20 & Not classified \\
\hline Fishing cat & 5 & 07:00 & 00:00 & 100 & Not classified \\
\hline Shikra & 3 & $13: 05$ & 00:00 & 100 & Not classified \\
\hline Chestnut-crowned bush warbler & 3 & $06: 48$ & 00:00 & 100 & Not classified \\
\hline Asian giant tortoise & 3 & -- & -- & 100 & Not classified \\
\hline Northern forest crested lizard & 3 & $06: 11$ & 00:00 & 100 & Not classified \\
\hline Bengal monitor & 3 & $10: 03$ & -- & 100 & Not classified \\
\hline Large woodshrike & 2 & $09: 36$ & 00:09 & 100 & Not classified \\
\hline Red collared dove & 1 & $07: 25$ & - & 100 & Not classified \\
\hline Greater racquet-tailed drongo & 1 & $08: 21$ & - & 100 & Not classified \\
\hline
\end{tabular}




\section{The factors affecting the distribution of wildlife and suitable habitats}

This study revealed that the formula used to analyze the average home range could analyze 13 wildlife species and reported the average area under the curve (AUC) value of $90.49 \%$. When considering the values used to measure the importance of the environmental variables that affect the presence of wildlife in the study area from the average \% contribution, it showed that the factor that had the highest effect on the presence of wildlife was the highway with the $\%$ contribution of $54.66 \%$, followed by land use (12.33\%), community location $(8.81 \%)$ and the normalized difference vegetation index (NDVI) in the study area (8.16\%). Similarly, when considering the permutation importance, we found that the most important factor was the highway which was $51.67 \%$, followed by ranger station location $(13.79 \%)$, community location $(13.65 \%)$ and the normalized difference vegetation index (NDVI) $(8.64 \%)$ in the study area. Details are shown in Table 4.

\section{Discussion}

The results from continuous monitoring of the wildlife diversity along the Highway 304 between Khao Yai National Park and Thap Lan National Park revealed 51 species, consisting of 30 species of mammals (including 15 species of carnivorous mammals and 15 species of noncarnivorous mammals), 17 species of wild birds and 4 species of reptiles. This study recorded more species than previous studies in Thailand, for example, the camera trap study by Kolasartsanee (2021), who recorded 15 species of mammals in Khao Soi Dao Wildlife Sanctuary, Chanthaburi Province and the mammal diversity study of Jenks et al. (2011) in KYNP who recorded 14 species of carnivorous and 12 species of non-carnivorous mammals (with a total of 26 species). Sukmasuang et al. (2020b) reported 14 species of carnivorous mammals in Khao Ang Rue Nai Wildlife Sanctuary from a camera trap survey. In contrast, Khoewsree et al. (2020) reported 19 species of carnivorous mammals and 14 species of non-carnivorous mammals adding to a total of 33 species. The species found in this study, but not in Khoesree et al. (2020), include the Fishing Cat. In this study, we did not record Marbled Cat, Crab-eating Macaque, Smooth-coated Otter, Yellowthroated Marten and Asiatic Brush-tailed Porcupine. This study shows that we recorded more species than in Huai Kha Khaeng Wildlife Sanctuary, which also used a camera trap survey and recorded 16 species of carnivorous mammals and 13 species of herbivorous mammals adding to a total of 29 species (Charaspet et al. 2019). This study contributes to more valid and accurate data on the wildlife diversity in Khao Yai National Park, Dong PhrayayenKhao Yai Forest Complex, the world's natural heritage site that has an outstanding diversity of wildlife. In particular, the record of a Fishing Cat is the first photographic sighting within the area. Finding habitat sites at the side of the highway at high risk of threat is a concern for protecting this species and various other threatened wildlife species that were found along the highway.

The evenness index of the species shows the distribution of the abundance between species in the community, which if high means the abundance of wildlife in the community is similar. The biodiversity index of wildlife $(\mathrm{H})$ in the studied area was 1.98 , which is in the moderate diversity level, while the evenness was 0.88 , showing a stable wildlife community in the study area. The results were at a good level each year and had a steady trend. The diversity index and the evenness index of the species in this study are higher than the study by Herawati et al. (2019), who reported the diversity and evenness index of freshwater fish in Cipanas River, West Java, Indonesia to be 1.20 to 2.08 and 0.27 to 0.47 , respectively.

The important wildlife species found along the underpass corridor include Gaur, Serow, Sambar Deer, Northern Red Muntjac, Wild Boar, Leopard Cat, Golden Jackal, Dhole, Malayan Porcupine, Hog Badger and Civets. However, the Clouded Leopard, Asiatic Black Bear, Leopard Cat, Gaur, Sambar Deer and Serow used the overpass. Furthermore, camera trap surveys showed that Serow, Hog Badger, Malayan Porcupine and Water Monitor used the tunnels under the road connecting the two national parks, the safest from disturbance. Wild elephants have not been shown to cross the road or use any corridors.

The results of this study showed the richness of the study area and indicated that there should be preventive measures, as well as reduction of the impact of human activities on wildlife in the area, especially the transportation on this highway and other activities occurring in the surrounding area including agriculture and waste disposal which may attract wildlife to consume. A total of 16 species in the area were listed under the IUCN Red List with species 2 being Critically Endangered, 3 Endangered, 10 Vulnerable, 1 Near Threatened and 32 Least concerned. If there is no action other than the sole declaration of a national park without any additional protection measures, it will lead to the disappearance of these wild species.

In this study, we had the first camera trap record of a Fishing Cat in the area. Giridhar (2016) reported the distribution of Fishing Cats in Asia, which does not include forest areas in the mainland that are not connected to the sea of Southeast Asia. However, Appel (2016), Duckworth (2016) and Willcox (2016) reported that the distribution of Fishing Cats remains unclear. The continuous camera trap monitoring in this study confirms the range of Fishing Cats in the corridor connecting the two national parks, indicating the importance of the habitat. The results of studying the wildlife activities from species with more than 20 images recorded, most of them (13 species) were nocturnal, while 12 species were diurnal, and 3 species were cathemeral. 
Table 4. Factors that affect the presence of some wildlife species analyzed using MaxEnt and the camera traps data recorded in the study area along the Highway 304 during 2017-2021 and environmental data

\begin{tabular}{|c|c|c|c|c|c|c|c|c|c|c|c|c|c|c|c|}
\hline & Parameter & $\begin{array}{c}\text { Greater } \\
\text { hog badger }\end{array}$ & $\begin{array}{c}\text { Leopard } \\
\text { cat }\end{array}$ & $\begin{array}{c}\text { Common } \\
\text { palm civet }\end{array}$ & $\begin{array}{c}\text { Red } \\
\text { muntjac }\end{array}$ & Gaur & Serow & $\begin{array}{c}\text { Sambar } \\
\text { deer }\end{array}$ & $\begin{array}{l}\text { Wild } \\
\text { boar }\end{array}$ & $\begin{array}{c}\text { Pig-tailed } \\
\text { macaque }\end{array}$ & Porcupine & Rat & $\begin{array}{l}\text { Siamese } \\
\text { fireback }\end{array}$ & $\begin{array}{c}\text { Red jungle } \\
\text { fowl }\end{array}$ & Average \\
\hline \multirow{9}{*}{ 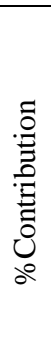 } & $\%$ AUC & 83.97 & 99.94 & 99.13 & 97.28 & 96.60 & 43.54 & 80.70 & 98.23 & 97.85 & 87.50 & 96.55 & 98.96 & 96.18 & 90.49 \\
\hline & Dem & 0.00 & 0.00 & 0.00 & 1.68 & 0.02 & 0.88 & 0.09 & 0.00 & 0.19 & 0.00 & 0.00 & 0.09 & 0.00 & 0.23 \\
\hline & Land use & 34.27 & 0.07 & 27.43 & 4.64 & 3.71 & 15.17 & 11.95 & 21.63 & 0.00 & 17.56 & 18.67 & 0.00 & 5.20 & 12.33 \\
\hline & NDVI & 0.02 & 18.65 & 0.00 & 3.27 & 11.22 & 0.02 & 0.57 & 0.00 & 18.21 & 22.76 & 0.00 & 30.33 & 1.04 & 8.16 \\
\hline & Ranger & 0.00 & 1.73 & 7.54 & 6.02 & 1.46 & 5.07 & 10.63 & 2.26 & 4.29 & 1.79 & 18.29 & 27.89 & 7.95 & 7.30 \\
\hline & Road & 51.91 & 75.82 & 55.05 & 50.77 & 54.09 & 63.01 & 59.94 & 42.36 & 46.89 & 49.95 & 60.87 & 27.19 & 72.76 & 54.66 \\
\hline & Slope & 0.15 & 0.00 & 1.77 & 0.00 & 0.04 & 0.00 & 1.49 & 0.00 & 7.87 & 1.27 & 0.00 & 5.17 & 0.00 & 1.37 \\
\hline & Village & 13.54 & 2.04 & 7.91 & 2.89 & 5.74 & 15.65 & 15.03 & 33.74 & 0.48 & 6.61 & 3.17 & 0.10 & 7.62 & 8.81 \\
\hline & Water & 0.09 & 1.66 & 0.30 & 30.74 & 23.76 & 0.20 & 0.29 & 0.00 & 22.07 & 0.06 & 0.00 & 8.68 & 5.43 & 7.18 \\
\hline \multirow{8}{*}{ 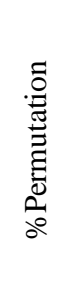 } & Dem & 0.00 & 0.00 & 0.00 & 0.00 & 0.92 & 0.00 & 0.86 & 0.00 & 1.31 & 0.00 & 0.00 & 2.21 & 0.00 & 0.41 \\
\hline & Land use & 1.48 & 1.28 & 9.04 & 12.83 & 4.06 & 4.33 & 3.67 & 17.81 & 0.00 & 13.01 & 2.28 & 0.00 & 4.89 & 5.74 \\
\hline & NDVI & 0.34 & 36.19 & 0.00 & 0.00 & 35.70 & 0.02 & 0.77 & 0.00 & 26.16 & 7.61 & 0.00 & 4.92 & 0.61 & 8.64 \\
\hline & Ranger & 0.00 & 26.93 & 26.81 & 0.00 & 0.00 & 2.33 & 10.38 & 0.00 & 2.07 & 0.00 & 14.23 & 85.90 & 10.67 & 13.79 \\
\hline & Road & 63.79 & 17.86 & 55.73 & 53.54 & 0.00 & 87.30 & 69.74 & 28.75 & 69.12 & 67.43 & 75.55 & 3.35 & 79.49 & 51.67 \\
\hline & Slope & 0.00 & 0.00 & 1.68 & 0.00 & 0.00 & 0.00 & 2.26 & 0.00 & 0.00 & 8.87 & 0.00 & 0.00 & 0.00 & 0.99 \\
\hline & Village & 34.38 & 15.14 & 5.36 & 13.83 & 15.28 & 5.63 & 12.31 & 53.44 & 1.33 & 3.09 & 7.94 & 3.61 & 6.14 & 13.65 \\
\hline & Water & 0.00 & 2.59 & 1.38 & 19.79 & 44.03 & 0.38 & 0.00 & 0.00 & 0.00 & 0.00 & 0.00 & 0.00 & 1.21 & 5.34 \\
\hline
\end{tabular}


In this study, Sambar Deer had the highest abundance, followed by Wild Boar, Northern Pig-tailed Macaque, Gaur, Northern Red Muntjac, Malayan Porcupine and Red Junglefowl. In the carnivorous group, the species with the highest abundance was the Common Palm Civet followed by Greater Hog Badger, Golden Jackal, Leopard Cat, Small Indian Civet and Dhole. The ground foraging bird species with the highest abundance was the Siamese Fireback, followed by the Red Junglefowl, Large-tailed Nightjar, Eastern Spotted Dove, Malay Night-heron and Chinese Pond-heron.

There was no difference in the abundance and diversity of the wildlife before and after the construction of the wildlife corridors. In addition, wildlife activities were seen around the corridor area throughout the day which confirms the constant use of wildlife. Therefore, human activities in the area should be taken with extreme caution due to the presence of wildlife considering the species, abundance and timing of exercise throughout the day.

It was also found that the highway is the factor that affects the wildlife presence the most, that showed the significance of the highway including the wildlife corridors affects the appearance of wildlife which shows the importance of various activities, especially on highway traffic that should be controlled significantly reducing the speed of the car, noise, lighting, because it hurts wildlife. The factors that affected wildlife presence included land use, villages, canopy coverage and water source but it happens in both positive and negative directions. This refers to other environmental factors that appear in areas other than highways that must be managed in parallel, such as reducing crops and prohibiting reduced water bodies developments near highways to reduce wildlife attraction. Results of the relative species and number, suitable habitat distribution, and time show the area's importance through which the highway passes. The construction of the wildlife corridors connecting the two national parks is significant for maintaining the continuity of the species population.

Suggestions inferred from the study results include the management of human activities in the area, including transportation, sound use, following the speed limit and maintaining the continuity of the tree canopy. In addition, according to the study, activities of humans living in the area, farming and waste disposal may attract wildlife closer to communities. This may affect wildlife management in the long run. The results show that the habitats of various types of wildlife are also suitable habitats for a wide range of species. However, currently this area, especially in the National Forest outside of TLNP, is occupied by people for farming, habitation and conducting activities outside of the main transportation route. Therefore, the constructed corridor between the two national parks must also address land issues that impede wildlife movement between the two national parks.

\section{ACKNOWLEDGEMENTS}

The researchers would like to thank the Department of National Parks, Wildlife and Plant Conservation for conducting research studies in the area. Department of Highways supported this research. They also thank Mr. Prawatsart Chanthep, Chief of Thap Lan National Park and Mr. Adisak Phusitwongsanuyut, Chief of Khao Yai National Park. We also would like to express our recognition to the Unit for Capital Development for Human Resource Development, Capital for Higher Education Development, Research, and Innovation Creation, Office of National Higher Education Science Research and Innovation Policy Council (NXPO) under the research project on the ecology of important wildlife in Khao Yai National Park for supporting Ph.D. students.

\section{REFERENCES}

Appel A. 2016. Fishing cat status in Vietnam. In: Appel A, Duckworth (eds). Proceedings of the First International Fishing Cat Conservation Symposium. Fishing Cat Working Group, Bad Marienberg, Germany and Saltford, Bristol, United Kingdom, 25-29 November 2015. [Nepal]

Azlan MJ. 2009. The use of camera traps in Malaysian rainforests. J Trop Biol Conserv 5: 81-86.

Berthinussen A, Altringham J. 2012. The effect of a major road on bat activity and diversity. J Appl Ecol 49 (1): 82-89. DOI: 10.1111/j.1365-2664.2011.02068.x

Caorsi VZ, Both C, Cechin S, Antunes R, Borges-Martins M. 2017. Effects of traffic noise on the calling behavior of two Neotropical hylid frogs. PLoS ONE 12(8): e0183342. DOI: 10.1371/journal.pone.0183342

Charaspet K, Sukmasuang R, Khoewsree N, Pla-ard M, Songsaen N, Simchareon S. 2019. Movement, home range size and activity pattern of the golden jackal (Canis aureus, Linneaus, 1758) in Huai Kha Khaeng Wildlife Sanctuary, Thailand. Biodiversitas 20 (11): 34303438. DOI: $10.13057 /$ biodiv/d20114

Duckworth JW. 2016. Fishing cat status in Vietnam. In: Appel A, Duckworth (eds). Proceedings of the First International Fishing Cat Conservation Symposium. Fishing Cat Working Group, Bad Marienberg, Germany and Saltford, Bristol, United Kingdom, 25-29 November 2015. [Nepal]

Duquette CA, Loss SR, Hovick TJ. 2021. A meta-analysis of the influence of anthropogenic noise on terrestrial wildlife communication strategies. J Appl Ecol 58 (6): 1112-1121. DOI: 10.1111/13652664.13880

Elith J, Graham CH, Anderson RP, Dudı'k M, Ferrier S, Guisan A, Hijmans RJ, Huettmann F, Leathwick JR, Lehmann A, Li J, Lohmann LG, Loiselle BA, Manion G, Moritz C, Nakamura M, Nakazawa Y, Overton JMM, Peterson AT, Phillips SJ, Richardson KS, ScachettiPereira R, Schapire RE, Sobero'n, J, Williams S, Wisz MS, Zimmermann, NE. 2006. Novel methods improve prediction of species' distributions from occurrence data. Ecography 29 (2): 129151. DOI: $10.1111 / \mathrm{j} .2006 .0906-7590.04596 . x$

Fahrig L, Rytwinski T. 2009. Effects of roads on animal abundance: An empirical review and synthesis. Ecol Soc 14 (1): 21. DOI: 10.5751/ES-02815-140121

Giridhar M. 2016. Fishing cat, Prionailurus viverrinus IUCN Red List Assessment of Threatened Species. DOI: 10.2305/IUCN.UK.20162.RLTS.T18150A50662615.en

Halfwerk W, Holleman LJM, Lessells CM, Slabbekoorn H. 2011. Negative impact of traffic noise on avian reproductivesuccess. J Appl Ecol 48 (1): 210-219. DOI: 10.1111/j.1365-2664.2010.01914.x 
Herawati H, Nurruhwati I, Dhahiyat Y. 2019. The structure of phytoplankton community to estimated trophic level in Jatigede reservoirs. Int. J Fish Aquat 4 (3): 33-37.

IUCN. 2005. Dong Phayayen-Khao Yai Forest Complex Thailand. IUCN World Heritage Evaluation Report May 2005, ID No 590 Rev.

IUCN. 2019. The IUCN Red List of Threatened Species. Version 2019-3. International Union for Conservation of Nature and Natural Resources. IUCN, Gland. https://www.iucnredlist.org

IUCN 2021. The IUCN Red List of Threatened Species. Version 2021-2. International Union for Conservation of Nature and Natural Resources. IUCN, Gland https://www.iucnredlist.org

Jenks K, Chanteap P, Peter C, Passanan C, Redford T, Lynam A, JoGayle H, Leimgruber P. 2011. Using Relative Abundance Indices from Camera-Trapping to Test Wildlife Conservation Hypotheses - An Example from Khao Yai National Park, Thailand. Trop Conserv Sci 4 (2): 113-131. DOI: $10.1177 / 194008291100400203$

Khoewsree N, Charaspet K, Sukmasuang R, Songsasen N, Pla-ard M, Thongbantum J, Kongchaloem W, Srinopawan K. 2020. Abundance, prey, and activity period of dholes (Cuon alpinus) in Khao Yai National Park, Thailand. Biodiversitas 21 (1): 345-354. DOI: 10.13057/biodiv/d210142

Kolasartsanee I. 2021. Diversity and habitat use of terrestrial mammals in the area proposed for water resource development in Khao Soi Dao Wildlife Sanctuary, Thailand. Environ Nat Resour J 19(3):186-194. DOI: 10.32526/ennrj/19/2020222

Kovach Computing Services. 2019. Oriana Program. https://www.kovcomp.co.uk/index.html

Krebs CJ. 1999. Ecological Methodology. 2nd Edition, Benjamin Cummings, Menlo Park,

Kvalseth TO. 2015. Evenness Indices Once Again: Critical Analysis of Properties. Springer Plus. DOI: 10.1186/s40064-015-0944-4

Laurance WF, Balmford A. 2013. A global map for road building. Nature 495: 308-309. DOI.org/10.1038/495308a

Laurance WF, Clements GR, Sloan S, O'Connell CS, Mueller ND, Goosem M, Venter O, Edwards DP, Phalan B, Balmford A, Van Der Ree R, Arrea IB. 2014. A global strategy for road building. Nature 513: 229-232. DOI: 10.1038/nature13717

Lekagul B, McNeely JA. 1988. Mammals of Thailand. Darnsutha Press, Bangkok.

Lekagul B, Round PD. 1991. A Guide to the Birds of Thailand Darnsutha Press, Bangkok.

Merow C, Smith MJ, Silander JA Jr. 2013. A practical guide to MaxEnt for modeling species' distributions: What it does, and why inputs and settings matter. Ecography 36 (10): 1058-1069. DOI: 10.1111/j.16000587.2013.07872.x

Meteorological Department. 2020. Climate Information. Climatological Centre, Prachinburi Province, Thailand. [Thai]

Northrup JM, Pitt J, Muhly TB, Stenhouse GB, Musiani M, Boyce MS. 2012. Vehicle traffic shapes grizzly bear behaviour on a multiple-use landscape. J Appl Ecol 49: 1159-1167. DOI: 10.1111/j.13652664.2012.02180.x

O'Brien TG, Kinnaird MF. 2011. Density estimation of sympatric carnivores using spatially explicit capture-recapture methods and standard trapping grid. Ecol Appl 21 (8): 2908-2916. DOI: $10.1890 / 10-2284.1$

Ouboter P, Kadosoe V. 2016. Three years of continuous monitoring of the large terrestrial mammals of Brownsberg Nature Park. Suriname. Acad J Sur 7: 643-660.

Phillips SJ, Dudik M. 2008. Modeling of species distributions with MaxEnt new extensions and a comprehensive evaluation. Ecography 31: 161-175. DOI: 10.1111/j.0906-7590.2008.5203.x
Pielou EC. 1966. The measurement of diversity in different types of biological collections. J Theor Biol 13: 131-144. DOI: 10.1016/00225193(66)90013-0

Polak T, Rhodes JR, Jones D, Possingham HP. 2014. Optimal planning for mitigating the impacts of roads on wildlife. J Appl Ecol 51 (3): 726-734. DOI: 10.1111/1365-2664.12243

Sawongfu M, Prayoon A, Aimampai K, Piyasomboon P, Tanhikorn S, Sribuarod K, Rojanadilok P, Pratumratanatarn S, Duangchantarasiri S, Hirunkairath K, Kanchanasaka B. 2011. Biodiversity, Abundance and Habitat Suitability of Wildlife in Corridor area between Khao Yai National Park and Thap Lan National Park. Wildlife Research Group, Wildlife Conservation Bureau, Department of Wildlife National Parks and Plant Conservation, Bangkok, Thailand. [Thai]

Shannon G, Crooks KR, Wittemyer G, Fristrup KM, Angeloni LM. 2016. Road noise causes earlier predator detection and flight response in a free-ranging mammal. Behav Ecol 27(5): 1370-1375. DOI: 10.1093/beheco/arw058

Sloan S, Campbell MJ, Alamgir M, Collier-Baker E, Nowak MG, Usher G, Laurance WF. 2018. Infrastructure development and contested forest governance threaten the Leuser Ecosystem, Indonesia. Land Use Policy 77: 298-309. DOI: 10.1016/j.landusepol.2018.05.043

Steinbeiser CM, Kioko J, Maresi A, Kaitilia R, Kiffner C. 2019. Relative abundance and activity patterns explain method-related differences in mammalian species richness estimates. J Mammal 100 (1):192-201. DOI: $10.1093 /$ jmammal/gyy175

Sukmasuang R, Charaspet K, Panganta T, Pla-ard M, Khioesree N, Thongbanthum J. 2020a. Diversity, abundance, activity period, and factors affecting the appearance of wildlife around the corridors between Khao Yai-Thap Lan National Parks, Thailand by camera trapping. Biodiversitas 21 (5): 2310-2321. DOI: 10.13057/biodiv/d210563

Sukmasuang R, Charaspet K, Reontik J, Pla-ard M. 2020b. Temporal overlap of carnivorous mammal community and their prey in Khao Ang Rue Nai Wildlife sanctuary, Chachoengsao Province, Thailand. Biodiversitas 21: 922-932. DOI: 10.13057/biodiv/d210310

TEAM network. 2008. Terrestrial Vertebrate Monitoring Protocol. v 3.0. Conservation International, Arlington, VA.

Ulfah M, Fajri SN, Nasir M, Hamsah K, Purnawan S. 2019. Diversity, evenness and dominance index reef fish in Krueng Raya Water, Aceh Besar. IOP Conf Ser Earth Environ Sci. 348: 012074. DOI: 10.1088/1755-1315/348/1/012074

UNESCO. 2021. Dong Phayayen-Khao Yai Forest Complex. UNESCO World Heritage Centre, https://whc.unesco.org/en/list/590/

van Schaik CP, M. Griffiths. 1996. Activity periods of Indonesian rain forest mammals. Biotropica 28 (1): 105-112. DOI: $10.2307 / 2388775$

Willcox D. 2016. Fishing cat status in Vietnam. In: Appel A, Duckworth (eds). Proceedings of the First International Fishing Cat Conservation Symposium. Fishing Cat Working Group, Bad Marienberg, Germany and Saltford, Bristol, United Kingdom, 25-29 November 2015. [Nepal]

Zaragozı B, Belda A, Gim'enez P, Navarro JT, Bonet A. 2015. Advances in camera-trap data management tools: Towards collaborative development and integration with GIS, Ecological Informatics 30 (2015): 6-15. DOI: 10.1016/j.ecoinf.2015.08.001

Zhang H, John R, Peng Z, Yuan J, Chu C, Du G, Zhou S. 2012. The relationship between species richness and evenness in plant communities along a successional gradient: A study from Sub-Alpine Meadows of the Eastern Qinghai-Tibetan Plateau, China. PloS ONE 7 (11): e49024. DOI: 10.1371/journal.pone.0049024 